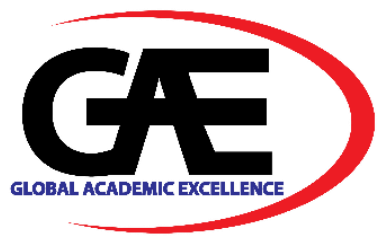

\title{
FACTORS THAT INFLUENCE ACCEPTANCE OF INFORMATION TECHNOLOGY TOWARDS MYSEJAHTERA APPS DURING COVID-19 PANDEMIC AMONG OLDER ADULTS IN KEDAH
}

Azahar Kasim $^{1 *}$, Siti Sofia Rozaini ${ }^{2}$

1 Senior Lecturer in Journalism at the School of Multimedia Technology and Communication, College of Arts and Sciences, 06010 Universiti Utara Malaysia, Sintok, Kedah, Malaysia

Email: w_azahar@uum.edu.my

2 Bachelor of Media Technology (with Honours) student in the School of Multimedia Technology and Communication, College of Arts and Sciences, 06010 Universiti Utara Malaysia, Sintok, Kedah, Malaysia

Email: sofiyarozaini@gmail.com

* Corresponding Author

\section{Article Info:}

Article history:

Received date: 10.10 .2021

Revised date: 15.11 .2021

Accepted date: 25.11 .2021

Published date: 01.12.2021

\section{To cite this document:}

Kasim, A., \& Rozaini, S. S. (2021). Factors That Influence Acceptance of Information Technology Towards MySejahtera Apps During Covid-19 Pandemic among Older Adults in Kedah. International Journal of Law, Government and Communication, 6 (26), 90-107.

DOI: $10.35631 /$ IJLGC.626008.

This work is licensed under $\underline{\text { CC BY } 4.0}$

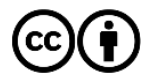

\section{Abstract:}

Coronavirus (COVID-19) is a virus originating in Wuhan, China. According to the World meter portal, as of Aug 2, 2021, a total of 199,008,754 out of 222 countries have been infected, and 4,240,331 have reportedly died due to the outbreak. A total of 17,149 cases are from Malaysia; the disease that interferes with this respiratory system has received severe coverage by the media worldwide. A new information technology which is MySejahtera apps has been created to convey the latest information. Following the role of this information technology as a significant contributor in channeling information to the community, especially among the group of older adults in Kedah. This study was conducted to determine whether the older adults can adapt to the new technologies like MySejahtera apps as a new norm and the general question of what influences the older adults to accept the MySejahtera apps can provide an easier way for them to find out the current information. This study was conducted quantitatively, and Technology Acceptance Model was used in this study. A total number of 140 older adults were chosen as a respondent to respond to the questionnaires. The results found that the acceptance of MySejahtera apps variables significantly influences the acceptance of information technology among older adults. There are no relations between the residential area and the type of network used by the older adults.

Keywords:

MySejahtera Apps, Older Adults, Technology Acceptance Model, Information, Influence, Acceptance. 


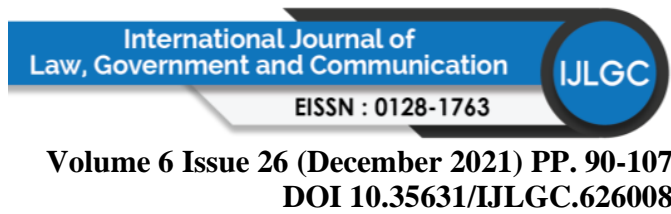

\section{Introduction}

Over the past 20 years, technology has advanced significantly. For example, the Internet has expanded a wide range of opportunities for people of all ages and making it easier for them to purchase, work, and learn (Lee, 2002). But most young people find it easier to use because they have grown up with modern technology. On the other hand, older adults are less likely to use modern technologies, particularly those who have never used the Internet or a smartphone might be unaware of how technology can benefit them (Vaportzis, 2017). Health and mobility technology for older adults has improved dramatically in the previous decade, including the Internet and mobile devices. The traditional pendant alarm to cutting-edge GPS alarms is all examples of lifeline alarms. Since the pandemic began, we have become much more reliant on technology to communicate or find any information related to the current situation. Thus, the technology works and provides advantages to the user. COVID-19 is caused by a novel coronavirus two that causes severe acute respiratory syndrome (SARS-CoV-2). Containment and mitigation of the pandemic have been emphasized due to its high transmissibility, high case fatality rate, and lack of viable antiviral medicine or vaccine. (Whitelaw, Mamas, Topol, \& Van Spall, 2020).

As a result of relying on well-established concepts of public health, governments worldwide have a different degree of success in reducing COVID-19's impact. In ways that are impossible to achieve manually, digital health technology can help with pandemic strategy and response in various ways. South Korea has integrated digital technology into government-coordinated containment and mitigation efforts such as testing, contact tracing, and strict quarantine (Heo, Lee, Seo, \& Choi, 2020). This could be linked to the early flattening of the incidence curves in South Korea and other Asian countries. Kumar, Sood, Gupta \& Sood, 2021). In some countries, big data and artificial intelligence (AI) have aided in COVID-19 preparedness and tracking and disease transmission. Chinese officials were able to track the movements of people who had visited the Wuhan market, the pandemic's epic center, using techniques like migration maps, which use mobile devices, digital payment apps, and media platforms to collect real-time data on people's movements (Liu, 2020)

According to Drees (2020), in the United States, Swedish Health Systems, a healthcare company, has formed a platform that enables healthcare workers to submit actual data on COVID-19 patient volumes, safety equipment, additional staff, nebulizer usage, and other resource-related information. The information was shared to keep track of hospital conditions, distribute health care resources, and increase hospital bed capacity. Because of the need to keep records of COVID-19, dashboards were created that visually show the sickness burden. Meanwhile, Whitelaw, Mamas, Topol, and Van Spall, 2020 mention data from the Singapore Ministry of Health is used to show infection patterns by age, sexuality, and location and the time required for infected individuals to recover.

In Malaysia, MySejahtera applications, a new information technology, have been developed to deliver the most up-to-date information. The Malaysian government created the MySejahtera app to help with the control of COVID-19 outbreaks around the country. It aids users in selfevaluation of their own and family members' health. During the COVID- 19 outbreak, users can still track their health improvement. Furthermore, the Ministry of Health $(\mathrm{MOH})$ can use the MySejahtera program to monitor users' health and respond quickly to provide appropriate remedies (Government of Malaysia, 2021). The MySejahtera application is intended to assist the government in managing and reducing the COVID-19 outbreak and helping users maintain 


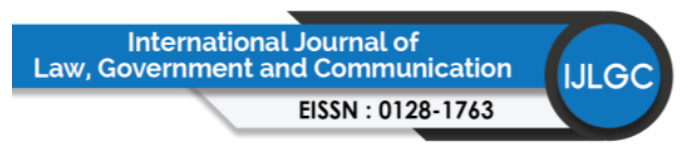

Volume 6 Issue 26 (December 2021) PP. 90-107

DOI 10.35631/IJLGC.626008

their health during the attack. Apart from that, if a user is infected with COVID-19, this application can assist them in obtaining treatment and locating nearby hospitals and clinics for examination and treatment. According to Tan Sri Dato' Seri, Dr. Noor Hisham bin Abdullah, Director-General of Health, said that MySejahtera apps had identified 9,167 COVID-19 cases. Through contact tracing methods such as local district health offices using MySejahtera's database and tracking potential COVID-19 patients' close contacts since its launch in April 2020.

MySejahtera is a strategic collaboration between the National Security Council (NSC), the Ministry of Health (MOH), the Administrative Transformation and Management Planning Unit of Malaysia (MAMPU) and the Malaysian Communications and Multimedia Commission (MCMC) and the Ministry of Research, Technology, and Innovation (MOSTI). It can be used by Malaysians and Malaysian citizens and by the MOH System Administrator. To support the enactment of the Infectious Diseases Prevention and Control Act 1988 [Act 342], MySejahtera was created. Under Section 22 of the Infectious Disease Prevention and Control Act, 1988 [Act 342] and Section 233 of the Communication and Multimedia Act 1998 [Act 588.], presenting false information is an offense. Following the role of social media as a significant contributor in channeling information to the community, this study was conducted to address the general question of what influences the older adults to accept the information technology towards MySejahtera apps.

\section{Problem Statement}

Digital health initiatives can exacerbate socioeconomic inequalities in health care by widening health care gaps. A common form of digital technology is the Internet and smartphone. Even though 4 billion people used the Internet in 2019, high-income areas used it more than low and middle-income regions did. Undefended groups may suffer from inadequate access to internet signals, smartphones, or wearable technology such as smartwatches, even in countries with high-income levels. Interventions should be targeted to places where broadband access necessitates federal and private sector investment in technology and infrastructure to deploy digital technologies abroad effectively.

The most critical disease reported worldwide was the COVID-19 pandemic that first became known in Wuhan, China, around the middle of December 2019. The global COVID-19 pandemic has infected more than 26.9 million people and has lost more than 880,000 lives so far. Furthermore, the rise of coronavirus infection has radically altered human life patterns and stifled economic growth. MySejahtera Check-In is a feature of the MySejahtera application that allows all sorts of businesses to follow the Government of Malaysia's Economic Reopening SOP in the case of a COVID -19 outbreak in Malaysia. Businesses, premises, public transportation, and other organizations who need to get and display MySejahtera QR Codes should register for MySejahtera Check-In. This study was conducted to determine whether older adults can adapt to the new technologies like MySejahtera apps as a new norm in their lives. There are limited studies regarding the acceptance of information technology towards MySejahtera apps, resulting in a lack of information. Aside from that, many researchers from other cultures and countries researched various scopes and methods. So, this study will understand what influences users to accept new technology, MySejahtera apps among the older adults in Kedah and the relation between the residential area and type of networks that the older adults used. 


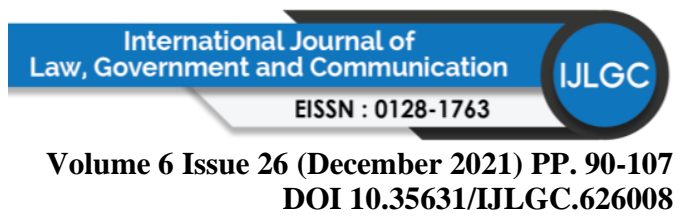

Hence, this research investigates the relationship between perceived usefulness, ease of use, and user satisfaction. The study also examines how perceived effectiveness, ease of use, and user satisfaction affect the acceptance of information technology towards MySejahtera apps. During COVID-19 pandemic among older adults in Kedah using this new technology, is there any relation between the residential area and type of network for them to use the application? So, to understand the driving forces toward the acceptance of the information and their relationship with perceived usefulness, perceived ease of use, and attribute of usability, it is essential to recognize how the older adults accept the information that has been conveyed through the MySejahtera apps during the Covid-19 situation.

\section{Research Questions}

i. Is there any relationship between perceived usefulness, perceived ease of use and user satisfaction with the acceptance of information technology towards MySejahtera apps among older adults in Kedah?

ii. Is the place that older adults leave relatable with the type of network used by older adults in Kedah?

\section{Research Objectives}

i. To identify the relationship between perceived usefulness, ease of use, and user satisfaction with the acceptance of information technology towards MySejahtera apps among older adults in Kedah.

ii. To relate the residential area and the types of networks used by older adults in Kedah.

\section{Literature Review}

\section{The Acceptance of Information Technology Among Adults}

Despite the notion that older persons have a right to full involvement in the globalized digital society that is continually evolving, there remain digital inequities based on age (Andreasson, 2015). This is supported by research showing that older adults have lower levels of technology adoption and are less inclined to accept new technologies (Broady et al., 2010). According to Shin et al. (2017), humans are applicable to social behavior theories of technology usage that support the mediating role of intention on attitude. He will provide a possible explanation for the fall in internet use (Ball et al., 2017). Physical and cognitive changes associated with aging (Pillay et al., 2006), poor network connectivity due to financial constraints (Andreasson, 2015), ageism (Barnard et al., 2013; WHO, 2018), or decreased perceived utility and social support in pediatrics could all contribute to the decline in communication technology use (Shin et al., 2017).

World Health Organization (WHO), 2018, older people might learn and accept the new technologies, resulting in social, psychological, physical, and economic advantages (Olphert and Damodaran, 2013). However, as digital technology advances, older people increase their mobile phones to stay connected (Chipps and Jarvis, 2017). Growing use may be accompanied by technology anxiety and a greater need for technical and social support, resulting in low selfesteem (Lee and Coughlin, 2015). 


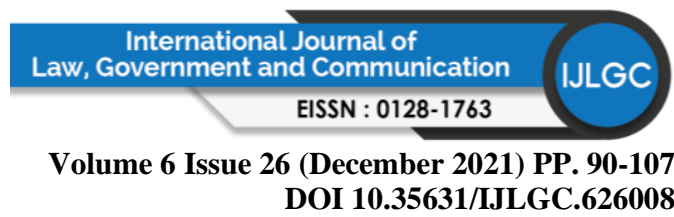

To encourage e-inclusion (Andreasson, 2015), mobile phone access, and enhanced digital competence for older people, the World Health Organization (WHO) and the United Nations (UN) published policies papers on health programs and interventions for older people (AlShorbaji, 2013). However, further research is needed on smartphones and technology adoption among older people, particularly in low-resource settings, specifically in the MySejahtera application during the pandemic.

\section{Application Technology}

Increased Usage Behavior (UB) is a result of increasing technical acceptability, according to the Technology Adoption Model (TAM) (Davis et al., 1989). According to the TAM theory, perceived Ease of Use (PEU) and Perceived Usefulness (PU) of technology would predict higher UB. Perceived utility (PU) is defined in the TAM as the user's perception of the device or application's convenience and efficacy. Using the device or application will improve the individual performance in the context of usage (Davis et al., 1989). A further discussion was had by Shin et al. (2017) on how important it is to have a positive point of view about the product and its credibility that subsequently changes into trust when the user realizes how helpful the product is. It is defined as a user's perception of the level of understanding needed to utilize the communication technology. With an emphasis on how enjoyable and straightforward the technology was to use (Davis et al., 1989), PEU and PU, which affect Behavioural Intention (BI), determine affective attitudes toward technology usage (AT) in the TAM (Chen and Chan, 2014). Online platforms are, by their very nature, addicting (Alter, 2017). Individuals commonly spend extended time online on social media because they encourage endless scrolling and lack a clear "stop point." Similar phenomena can be witnessed when watching online or YouTube news videos, where one can follow links continuously without coming to a clear and defined conclusion. This could be particularly challenging while attempting to navigate the ever-changing COVID-19 landscape.

However, technology acceptance in the elderly is complicated. Additional factors such as anxiety and self-efficacy toward technology and facilitating conditions such as technical assistance and technology knowledge, as well as financial resources and social network influences, may all play a role (Chen and Chan, 2014). The ability to perform technologyrelated activities has been shown to positively affect PEU and predict UB (Chen and Chan, 2014). Formalized created a structured codified, according to Chen and Chan (2014). According to the Unified Theory of Acceptance and Use of Technology (UTAUT) paradigm, they are Facilitating Conditions (FC) influence the practicality of employing communication technology (Barnard et al., 2013). Financial, environmental, human, and material resources are included in the definition of FC (Barnard et al., 2013; Chen and Chan, 2014; Van Biljon and Renaud, 2008). People using or planning to use a technological solution have access to human and environmental resources such as technology availability, training (Lee and Coughlin, 2015). In addition, Help Desks to relevant knowledge, social context of learning, social support, and social influences (Slegers et al., 2008). Instruction manuals with straightforward instructions (Leung et al., 2012), written in sans serif font size 14 with lots of white space (Gao et al., 2015), and stylus pens are examples of material resources (Van Dyk et al., 2012).

The Senior Technology Acceptance Model (STAM) established by Chen and Chan (2014), as well as the Senior Technology Acceptance and Adoption Model (STAAM) developed by Van Biljon and Renaud (2008), were evaluated while assessing technology acceptance in older individuals. According to Shin (2017), traditional techniques for determining a user's 


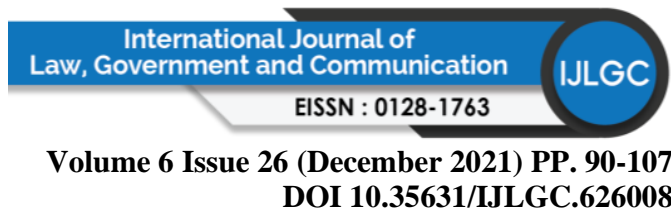

experience with technology are faulty since they fail to account for the quality of the encounter. Authors that approach technology adoption from a human-centered perspective (Saccol and Reinhard, 2006), who think that the quality of the technology experience is essential, have emphasized the significance of the quality of the technology experience. Saccol and Reinhard (2006) used a hospitality metaphor to equate new technology to a stranger, emphasizing the emotional component involved in the ultimate acceptance or rejection of a new technological breakthrough. Shin (2017) found that the experience of using technology influenced sentiments characterized as "affordance/coolness." This result was verified in younger individuals, despite being less significant in older ones. Despite the criticism, this study, which focused on older people, used a modified Technology Acceptance Model (TAM). The research was done to investigate how widely accessible and widely accepted communication technology is during this pandemic to implement and examine a MySejahtera Acceptance by older people in Kedah.

\section{Perceived Usefulness}

To describe the intention of people to embrace modern technologies, a range of models taken from different fields, such as psychology, sociology, and management, have been used. In several contexts, TAM has been commonly used to identify the determinants of technology acceptance, particularly to predict people's acceptance of information technology (Davis, 1989). Perceived usefulness is defined as how a user assumes that their performance will be improved by using the system (Dillon, 2001). Davis' study indicates that TAM can explain approximately 50 percent of the variance in acceptance levels for many regular office applications. The findings from many TAM studies indicate that usefulness is the most relevant predictor of usage; it explains more variance. Although significant inroads have been made into user adoption determinants, the difficult challenge remains to incorporate these observations in the design process to ensure that the resulting technologies are likely to be adopted. This raises the mutual task of assessing acceptance before any technology is wholly developed and then applying it in a way that facilitates adoption (Dillon, 2001).

$H_{1}$ : There is a positive relationship between perceived usefulness and the acceptance of information technology towards MySejahtera apps.

\section{Perceived Ease of Use}

Geffen and Straub (2000) argued that most research that expanded the TAM of Davis neglected to study the significance of the perceived ease of use (PEOU) in the adoption of information technology. Most studies have shown that PEOU affects the system's perceived utility, and usefulness, in turn, affects the user's intention to use information technology or its actual use. In their research, Geffen and Straub determined that PEOU affected adoption based on the task to be performed. The analysis also looked at PEOU's relationship to the intrinsic and extrinsic features of information technology. Inherent tasks were defined as tasks in which the technology itself provided the primary 'end' example of the product or service for which IT was used. The tasks in which IT was only the 'means' for achieving the primary product or service were classified as extrinsic tasks. To test their hypothesis, Geffen and Straub used a free simulation environment using an e-commerce website. The measures of usage were deemed to be a deliberate investigation and accurate purchase. They found that PEOU affects perceived usefulness, and both PEOU and perceived help affect the actual planned research and actual purchase on the e-commerce platform. Lucas and Spitler (1999) tested the effects of information systems used in their analysis of broker workstations. They concentrated their focus on the impact on the results of implementing information technology. Lucas and Spitler indicated that the use of the 


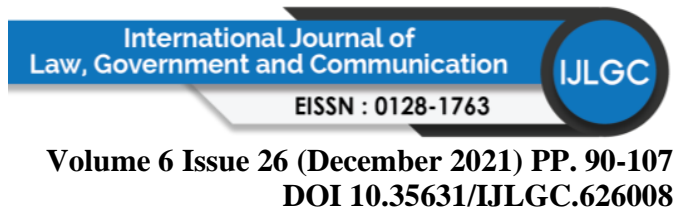

method positively influences the performance of brokers. Hence, the proposed hypothesis is;

$\mathrm{H}_{2}$ : There is a positive relationship between perceived ease of use and the acceptance of information technology towards MySejahtera apps

\section{User Satisfaction}

Previous studies have shown that the intent to use the service is positively related to satisfaction (Xu et al., 2010). For instance, Xu et al. (2010) revealed that user satisfaction positively impacts the active intention to use digital library resources. Similarly, Bhattacherjee (2001) discovered that the choice to keep using a system has a beneficial impact on initial satisfaction. Furthermore, Park and Del Pobil (2013) found that service and system satisfaction significantly affected the behavioral intention to utilize mobile communication services. This analysis, therefore, hypothesizes the following:

$\mathrm{H}_{3}$ : There is a positive relationship between user satisfaction and the acceptance of information technology towards MySejahtera apps

\section{Technology Acceptance Model (TAM)}

Davis (1989) created the Technology Acceptance Model, one of the most widely used research models for predicting individual users' use and acceptance of information systems and technology. TAM has been extensively researched and validated in multiple studies to examine the behavior of personal technology acceptance in various information system structures.

The Perceived Usefulness and Perceived Ease of Use constructs in TAM's core constructs are the most usually mentioned factors. This highlights the usefulness of TAM as a simple, predictive, and robust technique for assessing user acceptability of IT towards MySejahtera apps and their role in predicting user acceptance of information technology towards MySejahtera apps. The TAM was designed to predict and describe the acceptance of information obtained through social media by extending the belief attitude-intentionbehavior relationship in the TAM and TRA. According to the TAM, attitude, perceived usefulness, and perceived ease of use all play a role in deciding whether or not to accept technology. Individuals tend to use the application for its intended purpose, and attitudes towards technology influence the application's intention (Davis and Venkatesh, 2004).

Davis proposed the TAM to predict or elucidate the factors affecting IT use, which consisted of two beliefs which are perceived ease of use and perceived usefulness, which was based on Fishbein and Ajzen's TRA (theory of reasoned action) and Ajzen's TPB (theory of planned behavior), in which the TAM was expanded and developed. The former referred to a user's subjective assessment of IT's usability (information technology). The more user-friendly IT is, the more widely it is accepted. The latter referred to the degree to which users' subjective interpretations of information were valuable. The greater the utility, the more IT is used. Acceptance influenced attitudes and behavior. The research framework for this study involved three independent variables and one dependent variable based on the following hypothesis. The independent variables include three factors which are perceived usefulness, perceived ease of use, and user satisfaction. Meanwhile, the dependent variable is the acceptance of information technology towards MySejahtera apps. 


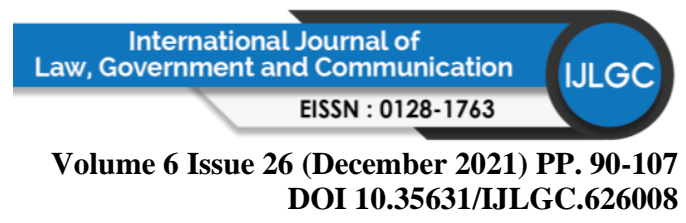

\section{Hypothesis Statement}

$\mathrm{H}_{1}$ : There is a positive relationship between perceived usefulness and the acceptance of information technology towards MySejahtera apps.

$\mathrm{H}_{2}$ : There is a positive relationship between perceived ease of use and the acceptance of information technology towards MySejahtera apps

$\mathrm{H}_{3}$ : There is a positive relationship between user satisfaction and the acceptance of information technology towards MySejahtera apps.

$\mathrm{H}_{4}$ : There is significantly relatable with the living area and the type of network that older adults in Kedah had used.

\section{Methodology}

This research is using the quantitative research method. The Statistical Package for Social Science (SPSS) system, version 26.0, was used to analyze the data in this study. All the findings are presented in a tabular form. The conclusions of this chapter are intended to expand on the responses to the research objectives and hypothesis. There were 384 questionnaires distributed to the older adults in Kedah. However, there are only $140(n=140)$ or responded to the questionnaire provided in a google form because not many people aged 40-60 years old use mobile technology to answer the questionnaires conducted through the google forms. Apart from that, there is also a limitation to distribute the printed questionnaire in the residential area because of the pandemic. Plus, the printed questionnaires could not be distributed at the workplace because most of them work from home. Two statistical tools were used to acquire the results of the data analysis. The first is descriptive statistics, which examines frequency findings and descriptive analysis. The inferential statistic, which is used to perform correlation and chi-square to identify the hypothesis, is the second tool. The following categories are used to explain the results of the data analysis, including demography analysis of respondents, descriptive study of respondents, and hypothesis testing as evaluation on the decision to accept or reject the research hypothesis.

\section{Descriptive Statistic}

\section{Descriptive Analysis Perceived Usefulness}

The descriptive analysis for the statement "MySejahtera apps allow users to register for Covid-19 vaccination program" has recorded the highest mean of 4.74 with a standard deviation of 0.51. Meanwhile, the statement related on "MySejahtera apps provides a space for me to know the location of the 'hotspot' of the virus throughout the country, just fill in the name of the location and all the information will be displayed" recorded the secondhighest mean of 4.49 with a standard deviation of 0.70 . apart from that, the statement "Using MySejahtera apps can enable me to save time when entering the premise" was in third place with a mean of 4.41 with a standard deviation of 0.83 . Finally, the statement "MySejahtera apps enable me to adjust well in current pandemic situation" recorded the lowest mean with a mean of 4.29 and a standard deviation of 0.77 . The overall mean for this section was 4.43 and the standard deviation was 0.55 . 
Volume 6 Issue 26 (December 2021) PP. 90-107 DOI 10.35631/IJLGC.626008

Table 1: Descriptive Analysis Perceived Usefulness.

\begin{tabular}{|c|c|c|}
\hline $\begin{array}{c}\text { Statement } \\
\text { (Perceived Usefulness) }\end{array}$ & MEAN & $\begin{array}{c}\text { STD. } \\
\text { DEVIATION }\end{array}$ \\
\hline MySejahtera apps can improve my adherence to SOP. & 4.31 & 0.74 \\
\hline $\begin{array}{l}\text { MySejahtera apps provide a space for me to know the location } \\
\text { of the 'hotspot' of the virus throughout the country, just fill in } \\
\text { the name of the site and all the information will be displayed. }\end{array}$ & 4.49 & 0.70 \\
\hline $\begin{array}{l}\text { Using MySejahtera apps can enhance my awareness of Covid- } \\
19 .\end{array}$ & 4.36 & 0.80 \\
\hline $\begin{array}{l}\text { Using MySejahtera apps can enable me to save time when } \\
\text { entering the premise. }\end{array}$ & 4.41 & 0.83 \\
\hline $\begin{array}{l}\text { MySejahtera apps allow the user to register for the Covid-19 } \\
\text { vaccination program. }\end{array}$ & 4.74 & 0.51 \\
\hline $\begin{array}{l}\text { MySejahtera apps enable me to adjust well to current pandemic } \\
\text { situation. }\end{array}$ & 4.29 & 0.77 \\
\hline Total & 4.43 & 0.55 \\
\hline
\end{tabular}

\section{Descriptive Analysis Perceived Ease of Use}

The results indicate that the statement related to "I think MySejahtera apps are easy to install in any devices" has recorded the highest mean of 4.63, with a standard deviation of 0.59 . Meanwhile, the statement related to "The language use in MySejahtera apps is easy and understandable for me" recorded the second-highest mean of 4.61 with a standard deviation of 0.60. The statement "I would find it easy to find out about the level of risk at the current location" was in ththird-placeith a mean of 4.46 with a standard deviation of 0.69 . Finally, the statement "I think it is easy for me to scan the QR Code when entering the premise without having a data connection" recorded the lowest mean with a mean of 3.10 and a standard deviation of 1.31. Thus, the overall mean for this section was 4.39 and the standard deviation was 0.56 .

Table 2: Descriptive Analysis Perceived Ease of Use

\begin{tabular}{lcc}
\hline \multicolumn{1}{c}{\begin{tabular}{c}
\multicolumn{1}{c}{$\begin{array}{c}\text { Statement } \\
\text { (Perceived Ease of Use) }\end{array}$} \\
$\begin{array}{l}\text { Learning to operate MySejahtera apps system would be } \\
\text { easy for me. }\end{array}$
\end{tabular}} & $\begin{array}{c}\text { MEAN } \\
\text { DEVIATION }\end{array}$ \\
\hline $\begin{array}{l}\text { I would find it easy to find out about the level of risk at the } \\
\text { current location. }\end{array}$ & 4.46 & 0.72 \\
\hline $\begin{array}{l}\text { The language use in MySejahtera apps is accessible and } \\
\text { understandable for me. }\end{array}$ & 4.61 & 0.69 \\
\hline $\begin{array}{l}\text { I think MySejahtera apps are easy to install on any device. } \\
\text { It is easy for me to scan the QR Code when entering the } \\
\text { premises without having a data connection. }\end{array}$ & 3.63 & 0.59 \\
\hline
\end{tabular}


Volume 6 Issue 26 (December 2021) PP. 90-107 DOI 10.35631/IJLGC.626008

It is easy for me to remember how to perform tasks using 4.41

0.73 the apps.

Total

\section{Descriptive Analysis User Satisfaction}

The results showed that the statement related to "This application is convenient because I no longer need to write my name and phone number every time I enter a store, I just need to scan the QR Code and every information can be seen in the application" has recorded the highest mean of 4.66 with a standard deviation of 0.55 . Meanwhile, the statement related to "I am completely satisfied while using MySejahtera apps to scan QR code" recorded the secondhighest mean of 4.52 with a standard deviation of 0.65. The statement "I think this application is very effective and it did not take a long time to scan the QR Code to record my current location" was in third place with a mean of 4.47 with a standard deviation of 0.69 . Finally, the statement "I feel very confident in using MySejahtera apps because it protected my personal information" recorded the lowest mean with a mean of 4.17 and a standard deviation of 0.78 . The overall mean for this section was 4.42 , and the standard deviation was 0.51 .

Table 3: Descriptive Analysis User Satisfaction.

\begin{tabular}{lcc}
\hline \multicolumn{1}{c}{$\begin{array}{c}\text { Statement } \\
\text { (User Satisfaction) }\end{array}$} & MEAN & $\begin{array}{c}\text { STD. } \\
\text { DEVIATION }\end{array}$ \\
\hline $\begin{array}{l}\text { I am completely satisfied while using MySejahtera apps to } \\
\text { scan QR codes. }\end{array}$ & 4.52 & 0.65 \\
\hline $\begin{array}{l}\text { I feel very confident in using MySejahtera apps because } \\
\text { they protect my personal information. }\end{array}$ & 4.17 & 0.78 \\
\hline $\begin{array}{l}\text { I found it easy to find any information for the current } \\
\text { situation about Covid-19 in MySejahtera apps. }\end{array}$ & 4.36 & 0.70 \\
\hline $\begin{array}{l}\text { I think this application is efficient and it did not take a long } \\
\text { time to scan the QR Code to record my current location. }\end{array}$ & 4.47 & 0.69 \\
\hline $\begin{array}{l}\text { The systems or interfaces in the apps are easy to understand } \\
\text { and suitable for every age. }\end{array}$ & 4.32 & 0.73 \\
\hline $\begin{array}{l}\text { This application is convenient because I no longer need to } \\
\text { write my name and phone number every time I enter a store, }\end{array}$ & 4.66 & 0.55 \\
$\begin{array}{l}\text { I just need to scan the QR Code and every information can } \\
\text { be seen in the application. } \\
\text { Total }\end{array}$ & & \\
\hline
\end{tabular}

\section{Descriptive Analysis User Acceptance}

After analyzing all the answers received from the respondents, the statement related to "I use MySejahtera apps very frequently" has recorded the highest mean of 4.59, with a standard deviation of 0.72. Meanwhile, the information related to "I use MySejahtera apps to check my date for vaccination" recorded the second-highest mean of 4.47, with a standard deviation of 0.73. The statement "I use MySejahtera apps as it provided me with the latest information regarding Covid-19 cases in Malaysia which is also updated daily and up-to-date" was in third place with a mean of 4.39 with a standard deviation of 0.77 . Finally, the statement "I use 
Volume 6 Issue 26 (December 2021) PP. 90-107 DOI 10.35631/IJLGC.626008

MySejahtera apps because it allows users to identify the nearest hospitals and clinics for examination and treatment" recorded the lowest mean with a mean of 4.03 and a standard deviation of 0.92 . Thus, the overall mean for this section was 4.31 and the standard deviation was 0.62 .

Table 4: Descriptive Analysis User Acceptance.

\begin{tabular}{lcc}
\hline \multicolumn{1}{c}{$\begin{array}{c}\text { Statement } \\
\text { (User Acceptance) }\end{array}$} & MEAN & $\begin{array}{c}\text { STD. } \\
\text { DEVIATION }\end{array}$ \\
\hline $\begin{array}{l}\text { I use MySejahtera apps very frequently. } \\
\begin{array}{l}\text { I use MySejahtera apps for various purposes such as } \\
\text { searching for information, checking my level risk info, etc. }\end{array}\end{array}$ & 4.59 & 0.72 \\
\hline $\begin{array}{l}\text { I use MySejahtera apps to avoid getting fine. } \\
\text { I use MySejahtera apps to check my date for vaccination. }\end{array}$ & 4.32 & 0.84 \\
\hline $\begin{array}{l}\text { I use MySejahtera apps because it allows users to identify } \\
\text { the nearest hospitals and clinics for examination and } \\
\text { treatment. }\end{array}$ & 4.03 & 0.90 \\
\hline $\begin{array}{l}\text { I use MySejahtera apps as they provided me with the latest } \\
\text { information regarding Covid-19 cases in Malaysia, which is } \\
\text { also updated daily. } \\
\text { Total }\end{array}$ & 4.39 & 0.92 \\
\hline
\end{tabular}

\section{Inferential Analysis}

\section{Correlation Analysis}

Pearson Correlation analysis was conducted to examine the relationships between independent variables and dependent variables. Based on the research conducted, there is a significant relationship between perceived usefulness and the acceptance of information technology towards MySejahtera apps. The statistical equation can be written as $(r(138)=0.687, \mathrm{p}<0.05$; The significant value shown is 0.000 where the value is much smaller than the set significance level of 0.05 . Hence, it indicates that there is a moderate connection between perceived usefulness and the acceptance of information technology towards MySejahtera apps. Thus, H1 is accepted.

\section{$H_{1}$ : There is a positive relationship between perceived usefulness and the acceptance of information technology towards MySejahtera apps.}

The relationship between perceived ease of use and the acceptance of information technology towards MySejahtera apps were also showed a significant relationship. Where $(\mathrm{r}(138)=0.615, \mathrm{p}<0.05$; The significant value shown is 0.000 where the value is much smaller than the set significance level of 0.05 . Hence, it indicates a moderate connection between perceived ease of use and the acceptance of information technology towards MySejahtera apps. Thus, $\mathrm{H} 2$ is accepted. 
Volume 6 Issue 26 (December 2021) PP. 90-107 DOI 10.35631/IJLGC.626008

$\mathrm{H}_{2}$ : There is a positive relationship between perceived ease of use and the acceptance of information technology towards MySejahtera apps.

Besides, H3 is accepted as the analysis result revealed a significant relationship between user satisfaction and the acceptance of information technology towards MySejahtera apps. The r-value between user satisfaction and the acceptance of information technology towards MySejahtera apps is equal to $(\mathrm{r}(138)=0.704, \mathrm{p}<0.05$; The significant value shown is 0.000 where the value is much smaller than the set significance level of 0.05 . Thus, this indicates that these variables also have a moderate relationship with the acceptance of information technology towards MySejahtera apps.

$\mathrm{H}_{3}$ : There is a positive relationship between user satisfaction and the acceptance of information technology towards MySejahtera apps.

Table 5: Correlation of the Major Variables

\begin{tabular}{lcccc}
\hline Item & Pearson & $\begin{array}{l}\text { Perceived } \\
\text { Usefulness }\end{array}$ & $\begin{array}{l}\text { Perceived } \\
\text { Ease of Use }\end{array}$ & $\begin{array}{l}\text { User } \\
\text { Satisfaction }\end{array}$ \\
\hline Perceived & Correlation & & $0.615^{* *}$ & $0.705^{* *}$ \\
Usefulness & Sig. $(2$ tailed $)$ & 0.000 & 0.000 & 0.000 \\
$\begin{array}{l}\text { Perceived Ease } \\
\text { of Use }\end{array}$ & $\mathrm{N}$ & 140 & 140 & 140
\end{tabular}

User Satisfaction

Acceptance of

Information Technology

** Correlation is significant at the 0.01 level ( 2 tailed)

Chi-square Analysis

The results in table 3 show the percentage of respondents' involvement in the residential area. The test value of Chi-Square with degrees of freedom of 8 , is 7.221. Thus, there was no relation between the 2 variables, and the statistical equation can be written as $\left(X^{2}(8), 7.221\right.$ $>0.05)$. The significance value was 0.513 and was found to be larger than the significance level of 0.05 . This indicates that the hypothesis constructed is rejected and fails to be accepted because there is no relation between the residential area and the type of network used by the older adults. However, the highest kind of network recorded in an urban area is Celcom network which is $(24.4 \%)$ compared to rural area which is $(20.6 \%)$

\section{$\mathrm{H}_{4}$ : There is no significant relatable between the living area and the type of network} that older adults in Kedah had used. 
Volume 6 Issue 26 (December 2021) PP. 90-107 DOI 10.35631/IJLGC.626008

Table 6: Chi-Square, The Relation Between Residential Area and Type of Network.

\begin{tabular}{|c|c|c|c|c|c|}
\hline Type of Network & Rural Area (\%) & $\begin{array}{c}\text { Urban Area } \\
(\%)\end{array}$ & $X^{2}$ & $\mathrm{df}$ & $\mathrm{p}$ \\
\hline Celcom & 20.6 & 24.4 & \multirow{10}{*}{7.221} & \multirow{10}{*}{8} & \multirow{10}{*}{0.513} \\
\hline Digi & 7.8 & 9.2 & & & \\
\hline Maxis & 10.1 & 11.9 & & & \\
\hline RedOne & 6.4 & 7.6 & & & \\
\hline & & & & & \\
\hline Tune Talk & 0.9 & 1.1 & & & \\
\hline Umobile & 4.6 & 5.4 & & & \\
\hline Unifi Mobile & 9.1 & 10.9 & & & \\
\hline XOX & 3.7 & 4.3 & & & \\
\hline YES Mobile_Yes 4G & 0.9 & 1.1 & & & \\
\hline
\end{tabular}

\section{Hypothesis Summary}

The results of the hypothesis testing conducted in this study are presented in Table 4.5. MySejahtera apps have shown a significant relationship with perceived usefulness, perceived ease of use, and user satisfaction, according to a bivariate Pearson's correlation coefficient analysis. Based on chi-square, two variables (area and type of network) indicate that the variables are not related.

Table 7: Hypothesis Summary

\section{Hypothesis}

Supported/Rejected

\section{Hypothesis 1}

$\mathbf{H}_{\mathbf{1}}$ : There is a positive relationship between perceived

Supported usefulness and the acceptance of information technology towards MySejahtera apps.

\section{Hypothesis 2}

$\mathbf{H}_{\mathbf{2}}$ : There is a positive relationship between perceived

Supported ease of use and the acceptance of information technology towards MySejahtera apps .

\section{Hypothesis 3}

$\mathbf{H}_{3}$ : There is a positive relationship between user

Supported satisfaction and the acceptance of information technology towards MySejahtera apps.

\section{Hypothesis 4}

$\mathrm{H}_{4}$ : There is a significant relatable with the living area and the type of network that had been used by older adults in Rejected Kedah. 


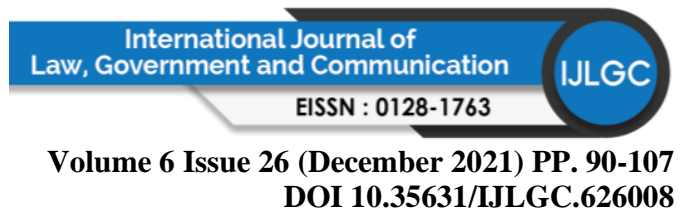

\section{Results of Correlation}

\section{Relationship Between Perceived Usefulness And The Acceptance Of Information Technology Towards Mysejahtera Apps Among Older Adults In Kedah.}

This research aims to determine what factors influence the older persons in Kedah to accept the information of technology in the MySejahtera apps during the Covid-19 Pandemic. As a result, stratified random sampling was used in this study, and the sample consisted of older adults living in Kedah.

Baker \& Stone (2020), findings also revealed the same things where the skills and ability to use the application will affecting the usefulness of the application. Perceived effectiveness was positively proven, contributing towards the use of the application. This finding is supported by Tubaishat, (2017), as he indicates that the practical application can affect the user. This study also proved that the service app's service helps the user be more engaged with the apps.

\section{Relationship Between Perceived Ease Of Use And The Acceptance Of Information Technology Towards Mysejahtera Apps.}

The findings on perceived ease of use are consistent with earlier research. The result on ease of service indicated that the more straightforward application is vital in determining the user acceptance on MySejahtera apps. Izuagbe, et al (2019) mentioned that a simple interface element in the apps will reflect the user's positiveness towards the approval of the application. Tahar, A., et al (2020) highlighted that the application's success and functionality are affected by the designer of the application where users find it easier to access than manually do it. Besides, ease of use is significant to make users adapt with the application.

\section{Relationship Between User Satisfaction And The Acceptance Of Information Technology Towards Mysejahtera Apps}

The user satisfaction factor is the most relevant variable that has a relationship with the acceptance of information technology towards MySejahtera apps. This finding is consistent with Che Hashim, et al (2018), where his research shows that the application functioning well is usable and is easy to use can make users feel satisfied with the apps. These results also supported by Song, J., et al. (2014), where he indicates that the facilitators play a role in affected user satisfaction in managing the application. This study also proved that user satisfaction helps draw the user's attention to use the apps.

\section{Results of Chi-Square}

\section{The Relation With The Living Area And The Type Of Network Used By Older Adults In Kedah.}

This study indicates that residential areas have no relation to the type of network that was the older adults in Kedah used. This is because the mobile network in Malaysia has its internet strength where each telco offers a variety of fast internet usage packages with low and affordable prices. They continually upgrade the web from time to time so that there is no interruption occurs. Thus, older adults have a good coverage range to cover the usage of MySejahtera apps. Moreover, the research shows that Celcom is the network most used by older adults in rural areas or urban areas because this network provides an affordable data package. 


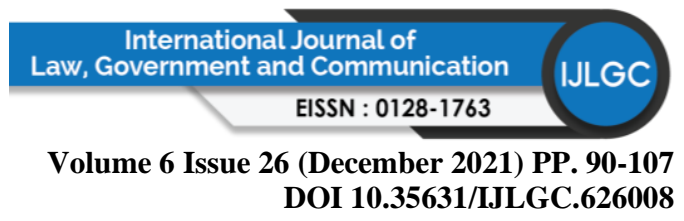

\section{Conclusion}

In conclusion, this research is to study the Factors That Influence Acceptance of Information Technology Towards MySejahtera Apps During Covid-19 Pandemic among Older Adults in Kedah. Overall, the study focuses on three factors which are perceived usefulness, perceived ease of use, and user satisfaction. The correlation analysis shows that all the factors (perceived effectiveness, perceived ease of use, and user satisfaction) positively correlate with the acceptance of MySejahtera apps. It also stated that the residential area of older adults has no relation between the type of network used by them. Thus, it can be concluded that every residential area has an excellent network to use the MySejahtera application.

Furthermore, Technology Acceptance Model was also successfully applied in this study and described how older adults could accept new application technologies such as MySejahtera as a new normed in their lives. Therefore, this study provides an impetus for future research on the acceptance of information technology towards MySejahtera apps among older adults in Kedah. Furthermore, it is hoped that a continual study on evaluating the application will be conducted, particularly from the standpoint of older adults.

\section{References}

Abu-Dalbouh, H. M. (2013). A questionnaire approach based on the technology acceptance model for mobile tracking on patient progress applications. J. Comput. Sci., 9(6), 763770 .

Al-Shorbaji, N. (2013). The World Health Assembly resolutions on eHealth: eHealth in support of universal health coverage. Methods of information in medicine, 52(06), 463-466.

Alter, A. (2017). Irresistible: The rise of addictive technology and the business of keeping us hooked. Penguin.

Alwahaishi, S., \& Snásel, V. (2013). Acceptance and use of information and communications technology: a UTAUT and flow based theoretical model. Journal of technology management \& innovation, 8(2), 61-73.

Amin, M., Rezaei, S., \& Abolghasemi, M. (2014). User satisfaction with mobile websites: the impact of perceived usefulness (PU), perceived ease of use (PEOU) and trust. Nankai Business Review International.

Andreasson, U., Perret-Liaudet, A., van Waalwijk van Doorn, L. J., Blennow, K., Chiasserini, D., Engelborghs, S., ... \& Teunissen, C. E. (2015). A practical guide to immunoassay method validation. Frontiers in neurology, 6, 179.

Askari, M., Klaver, N. S., van Gestel, T. J., \& van de Klundert, J. (2020). Too old to app? A cross-sectional study on intention to use medical applications among elderly in The Netherlands. Journal of Medical Internet Research.

Baker-Eveleth, L., \& Stone, R. W. (2020). User's perceptions of perceived usefulness, satisfaction, and intentions of mobile application. International Journal of Mobile Communications, 18(1), 1-18.

Ball, S. J. (2017). The education debate. Policy Press.

Banskota, S., Healy, M., \& Goldberg, E. M. (2020). 15 smartphone apps for older adults to use while in isolation during the COVID-19 pandemic. Western Journal of Emergency Medicine, 21(3), 514.

Barnard, M. (2013). Fashion as communication. Routledge.

Bhattacherjee, A. (2001). Understanding information systems continuance: An expectationconfirmation model. MIS quarterly, 351-370. 


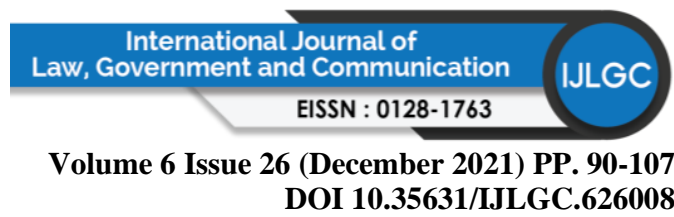

Broady, T., Chan, A., \& Caputi, P. (2010). Comparison of older and younger adults' attitudes towards and abilities with computers: Implications for training and learning. British Journal of Educational Technology, 41(3), 473-485.

Che Hashim, N., Abd Majid, N. A., Arshad, H., \& Khalid Obeidy, W. (2018). User satisfaction for an augmented reality application to support productive vocabulary using speech recognition. Advances in Multimedia, 2018.

Chen, K., \& Chan, A. H. S. (2014). Gerontechnology acceptance by elderly Hong Kong Chinese: a senior technology acceptance model (STAM). Ergonomics, 57(5), 635-652.

Chipps, J., Jarvis, M. A., \& Ramlall, S. (2017). The effectiveness of e-Interventions on reducing social isolation in older persons: A systematic review of systematic reviews. Journal of Telemedicine and Telecare, 23(10), 817-827.

Chopik, W. J. (2016). The benefits of social technology use among older adults are mediated by reduced loneliness. Cyberpsychology, Behavior, and Social Networking, 19(9), 551556.

Dasgupta, S., Granger, M., \& McGarry, N. (2002). User acceptance of e-collaboration technology: An extension of the technology acceptance model. Group Decision and Negotiation, 11(2), 87-100.

Davis, F. D. (1989). Perceived usefulness, perceived ease of use, and user acceptance of information technology. MIS quarterly, 319-340.

Davis, F. D., \& Venkatesh, V. (2004). Toward preprototype user acceptance testing of new information systems: implications for software project management. IEEE Transactions on Engineering management, 51(1), 31-46.

Dillon, A. (2001). User acceptance of information technology. London: Taylor and Francis.

Drees, J. (2020). 67\% of Patients Say Telemedicine Is Better than In-Person Visits, Survey Finds,". Becker's Hospital Review.

Eyisi, D. (2016). The usefulness of qualitative and quantitative approaches and methods in researching problem-solving ability in science education curriculum. Journal of Education and Practice, 7(15), 91-100.

Gao, W., Zhang, Y., Ramanujan, D., Ramani, K., Chen, Y., Williams, C. B., ... \& Zavattieri, P. D. (2015). The status, challenges, and future of additive manufacturing in engineering. Computer-Aided Design, 69, 65-89.

Gefen, D., \& Straub, D. (2000). The relative importance of perceived ease of use in IS adoption: A study of e-commerce adoption. Journal of the association for Information Systems, $1(8), 1-30$.

Heo, K., Lee, D., Seo, Y., \& Choi, H. (2020). Searching for Digital Technologies in Containment and Mitigation Strategies: Experience from South Korea COVID-19. Annals of Global Health, 86(1).

Hossain, L., \& de Silva, A. (2009). Exploring user acceptance of technology using social networks. The Journal of High Technology Management Research, 20(1), 1-18.

Izuagbe, R., Ibrahim, N. A., Ogiamien, L. O., Olawoyin, O. R., Nwokeoma, N. M., Ilo, P. I., \& Osayande, O. (2019). Effect of perceived ease of use on librarians'e-skills: Basis for library technology acceptance intention. Library \& Information Science Research, 41(3), 100969.

Jarvis, M. A., Sartorius, B., \& Chipps, J. (2020). Technology acceptance of older persons living in residential care. Information Development, 36(3), 339-353.

Johnson, E. M., \& Howard, C. (2019). A library mobile device deployment to enhance the medical student experience in a rural longitudinal integrated clerkship. Journal of the Medical Library Association: JMLA, 107(1), 30. 


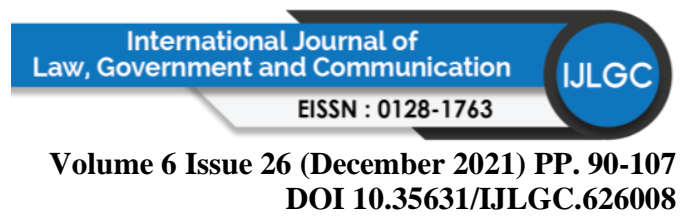

Kim, D., \& Chang, H. (2007). Key functional characteristics in designing and operating health information websites for user satisfaction: An application of the extended technology acceptance model. International journal of medical informatics, 76(11-12), 790-800.

Krejcie, R. V., \& Morgan, D. W. (1970). Determining sample size for research activities. Educational and psychological measurement, 30(3), 607-610.

Kumar, V., Sood, A., Gupta, S., \& Sood, N. (2021). Prevention-Versus Promotion-Focus Regulatory Efforts on the Disease Incidence and Mortality of COVID-19: A Multinational Diffusion Study Using Functional Data Analysis. Journal of International Marketing, 29(1), 1-22.

Lee, C., \& Coughlin, J. F. (2015). PERSPECTIVE: Older adults' adoption of technology: an integrated approach to identifying determinants and barriers. Journal of Product Innovation Management, 32(5), 747-759.

Lee, K. R. (2002). Impacts of Information Technology on Society in the new Century. Business and management, 5(6), 46-55.

Leung, P., Li, X., De León, C. P., Berlouis, L., Low, C. J., \& Walsh, F. C. (2012). Progress in redox flow batteries, remaining challenges and their applications in energy storage. Rsc Advances, 2(27), 10125-10156.

Liu, J. (2020). "Deployment of IT in China's fight against the Covid-19 pandemic.". ITNOnline.

Lucas Jr, H. C., \& Spitler, V. K. (1999). Technology use and performance: A field study of broker workstations. Decision sciences, 30(2), 291-311.

Ministry of Health (2021), MySejahtera.Malaysia, Retrieved Jun 3 2021, from https://mysejahtera.malaysia.gov.my/ .

Olphert, W., \& Damodaran, L. (2013). Older people and digital disengagement: a fourth digital divide?. Gerontology, 59(6), 564-570.

Park, E., \& del Pobil, A. P. (2013). Technology acceptance model for the use of tablet PCs. Wireless personal communications, 73(4), 1561-1572.

Pillay, B., Wootten, A. C., Crowe, H., Corcoran, N., Tran, B., Bowden, P., ... \& Costello, A. J. (2016). The impact of multidisciplinary team meetings on patient assessment, management and outcomes in oncology settings: a systematic review of the literature. Cancer treatment reviews, 42, 56-72.

Saccol, A. Z., \& Reinhard, N. (2006). The Hospitality Metaphor as a theoretical lens for understanding the ICT adoption process. Journal of Information Technology, 21(3), 154-164.

Sekaran, U., \& Bougie, R. (2019). Research methods for business: A skill building approach. john wiley \& sons.

Shin, S., Park, S., Park, M., Jeong, E., Na, K., Youn, H. J., \& Hyun, J. (2017). Cellulose nanofibers for the enhancement of printability of low viscosity gelatin derivatives. BioResources, 12(2), 2941-2954.

Slegers, K., Van Boxtel, M. P., \& Jolles, J. (2008). Effects of computer training and Internet usage on the well-being and quality of life of older adults: a randomized, controlled study. The journals of gerontology series B: Psychological sciences and social sciences, 63(3), P176-P184.

Soh, P. Y., Heng, H. B., Selvachandran, G., Chau, H. T. M., Abdel-Baset, M., Manogaran, G., \& Varatharajan, R. (2020). Perception, acceptance and willingness of older adults in Malaysia towards online shopping: a study using the UTAUT and IRT models. Journal of ambient intelligence and humanized computing, 1-13. 
Volume 6 Issue 26 (December 2021) PP. 90-107 DOI 10.35631/IJLGC.626008

Song, J., Kim, J., Jones, D. R., Baker, J., \& Chin, W. W. (2014). Application discoverability and user satisfaction in mobile application stores: An environmental psychology perspective. Decision Support Systems, 59, 37-51.

Tahar, A., Riyadh, H. A., Sofyani, H., \& Purnomo, W. E. (2020). Perceived ease of use, perceived usefulness, perceived security and intention to use e-filing: The role of technology readiness. The Journal of Asian Finance, Economics, and Business, 7(9), 537-547.

Tubaishat, A. (2018). Perceived usefulness and perceived ease of use of electronic health records among nurses: Application of Technology Acceptance Model. Informatics for Health and Social Care, 43(4), 379-389.

Van Biljon, J., \& Renaud, K. (2008, October). A qualitative study of the applicability of technology acceptance models to senior mobile phone users. In International Conference on Conceptual Modeling (pp. 228-237). Springer, Berlin, Heidelberg.

Van Dyk, J. S., \& Pletschke, B. I. (2012). A review of lignocellulose bioconversion using enzymatic hydrolysis and synergistic cooperation between enzymes-factors affecting enzymes, conversion and synergy. Biotechnology advances, 30(6), 1458-1480.

Vaportzis, E., Giatsi Clausen, M., \& Gow, A. J. (2017). Older adults perceptions of technology and barriers to interacting with tablet computers: a focus group study. Frontiers in psychology, 8, 1687.

Whitelaw, S., Mamas, M. A., Topol, E., \& Van Spall, H. G. (2020). Applications of digital technology in COVID-19 pandemic planning and response. The Lancet Digital Health.

Xie, I., \& Matusiak, K. (2016). Discover digital libraries: Theory and practice. Elsevier.

Yoon, H. Y. (2016). User acceptance of mobile library applications in academic libraries: an application of the technology acceptance model. The Journal of Academic Librarianship, 42(6), 687-693. 